\title{
Aspects of diversity in early Antarctic penguins
}

Piotr Jadwiszczak and Thomas Mörs

Acta Palaeontologica Polonica 56 (2), 2011: 269-277 doi: http://dx.doi.org/10.4202/app.2009.1107

Penguin bones from the Eocene La Meseta Formation (Seymour Island, Antarctic Peninsula) constitute the only extensive fossil record of Antarctic Sphenisciformes. Here, we synonymize some of the recognized genera (Anthropornis with Orthopteryx, Delphinornis with Ichtyopteryx) and species (Anthropornis nordenskjoeldi with Orthopteryx gigas, Delphinornis gracilis with Ichtyopteryx gracilis). Moreover, we suggest that Antarctic species of Anthropornis and Palaeeudyptes, so-called giant penguins, may in fact comprise only one species each instead of two, based on evidence of well-marked sexual dimorphism. We also present new estimates of body mass based on femora testifying to the impressive scope of interspecific body-size variation in Eocene Antarctic penguins.

Key words: Aves, Sphenisciformes, systematics, sexual dimorphism, body mass, Eocene, Antarctic Peninsula.

Piotr Jadwiszczak [piotrj@uwb.edu.pl], Uniwersytet w Białymstoku, Instytut Biologii, ul. Świerkowa 20B, PL-15-950 Białystok, Poland; Thomas Mörs [thomas.moers@nrm.se], Swedish Museum of Natural History, Department of Palaeozoology, P.O. Box 50007, SE-104 05 Stockholm, Sweden.

This is an open-access article distributed under the terms of the Creative Commons Attribution License (for details please see creativecommons.org), which permits unrestricted use, distribution, and reproduction in any medium, provided the original author and source are credited. 
